\title{
EDWARD SAID'S INTELLECTUAL LEGACY IN THE ARAB WORLD
}

\author{
SABRY HAFEZ
}

This article discusses Edward Said's intellectual legacy in the Arab world. After examining Said's own cultural influences, the trajectory of his early academic career in America, and his "re-orientation" towards his Arab identity and culture following the 1967 war, the author focuses on the reception of his works in Arab intellectual circles. Though Orientalism was initially misperceived through the frame of identity politics, his theoretical writings exerted a steadily growing impact on Arab criticism, particularly by offering a way out of its methodological dependency on the West. The author suggests that Said's final role as an oppositional intellectual "speaking truth to power," which reached beyond the Arab intelligentsia to a broader audience, may in the final analysis be his most lasting contribution.

IN HIS Representations of the Intellectual, Edward Said suggests that

as an intellectual I present my concerns before an audience or constituency. But this is not just a matter of how I articulate them, but also of what I myself, as someone who is trying to advance the cause of freedom and justice, also represent. I say or write these things because after much reflection they are what I believe; and I also want to persuade others of this view. There is therefore this quite complicated mix between the private and the public worlds, my own history, values, writings and positions as they derive from my experiences, on the one hand, and, on the other hand, how these enter into the social world where people debate and make decisions about $w$ ar and freedom and justice. ${ }^{1}$

In order to understand Said's intellectual legacy, his cultural project, and its impact on the Arab intellectual scene, it is essential to be keenly aware of this

\footnotetext{
SABRY HAFEz is professor of modern Arabic and comparative literature at the School of Oriental and African Studies, University of London. He is the author and editor of some twenty books in Arabic on poetry, drama, literary theory, and the Arab novel and short story (including works on Naguib Mahfouz, Yusif Idriss, and Mahmoud Darwish). His w orks in English include The Genesis of Arabic Narrative Discourse (Saqi, 1993) and several edited volumes, including A Reader of Modern Arabic Short Stories and Modern Arabic Criticism (Saqi, 2004).
}

Journal of Palestine Studies XXXIII, no. 3 (Spring 2004), pages 76-90. ISSN: 0377-919X; online ISSN: 1533-8614.

(c) 2004 by the Institute for Palestine Studies. All rights reserved.

Send requests for permission to reprint to: Rights and Permissions, University of California Press, Journals Division, 2000 Center St., Ste. 303, Berkeley, CA 94704-1223. 
"quite complicated mix." The mix that went into the making of this remarkable individual appealed, for many reasons and on many levels, to Arab intellectuals, enabling them to take pride in interacting with his cultural project.

\section{THE LegaCy OF THE ARAB-WeStERn INIERACTION}

As an Arab-Western intellectual, Edward Said is heir to the complex and often painful process of the Arab interaction with the West. This interaction has a long history, ${ }^{2}$ but its modern phase, of which Said is a product, goes back to the French expedition to Egypt in 1798. This brief encounter with the West had a seismic cultural impact on the Arabs. Though traditionalists assiduously attacked the changes that ensued, which they saw as assaults on Islam and Arab culture, Arab governments launched ambitious programs of modernization aimed at catching up with the West, particularly Europe. The initial success of those who embarked upon the path of modernity led to wide acceptance of this trajectory by Arab countries and individuals alike. Even the colonization by Western powers of many Arab lands in the last decades of the 19th century did not dampen the enthusiastic embrace by governments and urban elites of Western models in many areas of life. Thus, the early decades of the 20th century were increasingly marked by the adoption of Western (mainly European) educational systems, dress, and manners. The adoption of Western models also affected the cultural sphere, resulting in the genesis of modern Arabic narrative genres such as the novel, the short story, and drama. ${ }^{3}$

These early years of the last century were also marked by the emigration of large numbers of Arabs, especially Levantines, from Lebanon, Syria, and Palestine to the Americas, where most adopted many aspects of Western social and cultural life. Edward Said's father, Wadi' Said, was one of these émigrés, leaving Palestine for the United States in 1911 and remaining there for almost a decade. The years he spent in America were characterized by an increasingly vibrant cultural activity within the Arab intellectual community. (Two Arabic journals edited by Levantine émigrés were already being published. ${ }^{4}$ ) This activity influenced, and was influenced by, the cultural scene in their home countries. Indeed, in 1920, the year Wadi' Said returned to Palestine, a group of Levantine intellectuals in New York launched what was to become one of the most influential, innovative literary movements in modern Arab intellectual history-alRabitah al-Qalamiyyah (The Pen Association), headed by Jibran Khalil Jibran (1883-1931). ${ }^{5}$ That same year, in a separate but homologous development, the Diwan group was established in Cairo. ${ }^{6}$ Though the two groups had developed in isolation from one another, both reflected the same cultural trend underw ay among Arab intellectual elites since the turn of the century, notably the shift from a neoclassical to a romantic sensibility. As a result, they promoted similar ideas on innovations in literary styles. Ironically, it was the New York-based Pen Association, the first of the Mahjar (Diaspora) movements, ${ }^{7}$ that ultimately had the greater influence in shaping modern Arab literature; its ideas were disseminated through its journal al-Sa'ih, which reached the Arab world and where 
many of its articles were published in other journals. One of the reasons for its greater appeal was that while the Diwan group's patriotic agendas limited its impact to Egypt, the Pen Association was focused almost entirely on literary matters and its members were more familiar with the major works of European romanticism. ${ }^{8}$ At all events, their combined efforts, by influencing the next generation of poets and critics, culminated in the formation in 1932 of the Apollo Group, the first pan-Arab romantic literary movement, ${ }^{9}$ which further spread Western literary ideas and called for freeing poetry from traditional and archaic forms. Thus, the adoption of Western models, affecting lifestyles as much as cultural modes of expression and thought, was widespread at the time both in the Arab world itself and in Arab communities abroad. This was particularly pronounced among the Arab Christian minorities, who felt a stronger affinity with the West than their Muslim counterparts. This was the environment that shaped the actions and attitudes of Edward Said's father and that therefore had a direct impact on Edward Said's own educational and cultural formation.

\section{A WESTERN FORMATION}

Wadi' Said had returned to Palestine in 1920 at the insistence of his mother, and he moved to Cairo tow ard the end of the decade. Though he had returned to the Arab w orld and married in the traditional Arab way in 1932, his adoption of the Western model governed the rest of his life. While in America, he had changed his name to William, become an American citizen, and fought with the U.S. Army in France in World War I. ${ }^{10} \mathrm{H}$ is continuing identification with the West was clearly reflected in the naming of his children ${ }^{11}$ and in the education he gave them. His pride in his American citizenship - at a time when the United States was seen as the paragon of freedom and modernity and the champion of op pressed nations and minorities - was increased by his sense (as a Protestant) of being a minority even within the wider Christian Arab community.

Edward Said was born in Jerusalem in 1935, and though he enjoyed-like all his siblings but not his mother-American citizenship, he was brought up primarily in the colonial Egypt of the 1930s and 1940s, with intermittent visits to and vacations in Palestine. At the time Egypt, and particularly Cairo, was a turbulent place, full of contradictions and teeming with social and political movements spanning the whole political spectrum from the Muslim Brothers to the Communists, but Edward was raised in the protective cocoon of the liberal, cosmopolitan Egypt of foreigners and minorities. The first shock to his identity came in the mid 1940s when the British secretary of the Gezira Club, a Mr. Pilley, told him, "Arabs aren't allowed here, and you're an Arab."12 Yet there was what Said later called "a fatalistic compact between my father and myself about our necessarily inferior status. He knew about it, I discovered it publicly for the first time face to face with Pilley, yet neither of us saw it as worth a struggle of any kind, and that realisation shames me still." ${ }^{13}$

Shielded from the tragic consequences of the Palestinian Nakbah-the loss of the family home and the uprooting of many of his relatives- by his father's 
wealth and his American citizenship, he enjoyed without interruption the comforts of upper middle class life and the benefits of an elite private education. He went first to an English school in 1941, then to Cairo School for American Children in 1946, and, in 1949, to Victoria College, the school for the children of the colonial elite. In 1951, he went to the United States, and after a year at a preparatory school enrolled in Princeton University. His graduate studies at Harvard culminated in his doctoral thesis on Joseph Conrad in $1963 .{ }^{14}$ This education and cultural formation established his strong foundation in Western culture and methodology and ironically enhanced his appeal to Arab intellectuals two decades later. It also took him aw ay from the "inferior status" of the "Arab." Indeed, upon his arrival in America, his father had warned him to "stay aw ay from the Arabs. ... They'll al ways be a hindrance. They neither keep w hat is good about Arab culture, nor show any solidarity with each other." ${ }^{15}$ It seems that the son initially heeded the father's advice, neglecting his Arabic language and culture, specializing in English and comparative literature, and pursuing a career in American academia.

Yet the nagging sense of being "out of place" continued to haunt him, and the accumulation of "hurt" and "injustice"16 ultimately drove him back to the culture of his origins. One can now read Said's career retrospectively and see how his acute sense of being an "exile" and "out of place" led him to choose as the subject for his doctoral research Conrad, a writer who, like himself, experienced displacement both geographically and linguistically. This was a writer with whom Said shared the perspective of a decentered self, capable of seeing the culture of the "other" from within and from outside at the same time. Conrad was also a writer who raised issues of identity, uprooted and broken histories, subjectivity, and the dynamic tension between cultures and people.

Said's sense of exile also drove him to break new ground. In a move highly unusual for a young scholar writing his dissertation, he rejected the methodology of the New Criticism, which totally dominated American academia in the 1950s and 1960s. Finding the New Criticism's treatment of the text as a "verbal icon" divorced from the author's history, identity, vision, experience, and context inadequate to unlock the hidden meanings of Conrad's work, he opted for the more sophisticated approach of the Geneva School. ${ }^{17}$ This school eschew ed formalist or objective methods in favor of a phenomenological study of the text intended to reconstitute an author's worldview from his literary language. Said found its hermeneutic strategy, which probes the work for signals that disclose the structure of consciousness, more conducive to the underlying sense of displacement and exile at work in Conrad's texts. The Geneva School's concept that the author's projection of imaginative worlds are the key to his existential identity requires that the critic identify recurring patterns of spacetime experience in the author's work. This Said found useful in articulating the underlying structure of consciousness that attracted him to Conrad.

It was the publication of Said's accomplished work Beginnings: Intentions and Method, in 1975 that established his reputation not only as an erudite scholar of profound insights and acute critical judgment, but as one who set 
his own path. These were the years of the rise of literary theory in America, and instead of following, as did many of his contemporaries, the Russian formalists or the French structuralists or deconstructionalists (whose theories he had nonetheless deeply absorbed), he developed his own theoretical genealogy. He rooted his project neither in the semiotic structuralist genealogy that led eventually to deconstruction (as did the Yale critics) nor in Marxist literary theory (as did Raymond Williams and Fredric Jameson, among others). Instead, in his intransitive Beginnings, he went back to the overlooked w orks of Giambattista Vico, whose The New Scienœ (1725) questions at that early date the universality of know ledge and the certitude of accepted convictions and establishes the historicity of these concepts. He then combined Vico's concept of knowledge with the archaeology of Michel Foucault, after subjecting this last to a rigorous Nietzschean questioning of its origin and purpose. From this he posits his unique theory of "the novel as beginning intention." By the time he wrote Orientalism, he had modified this theoretical approach by incorporating the contribution of Antonio Gramsci, who highlighted the role of national identity and geographical locations in our perception of culture and thought. The use of Gramsci's w ork and the dialogue with his ideas coincided with Said's discovery of the work of the Frankfurt School, and particularly of Theodor Adorno and Walter Benjamin. In his later work, Said became closer to Adorno, his ideas and critical method, than to any other thinker. This is not only because Said shares Adorno's passion for music and admires his writing on it, but also because of the breadth, variety, and individuality of his thinking and his ability to blend the creative, critical, and philosophical elements in a lucid and impossibly simple style. The same could be said of Said. More importantly, if Adorno has offered us through his "negative dialectics" the theory of the untheorizable in philosophy and music, Said has achieved a similar theorization in the literary field. Like Adorno, Said emphasized the importance of individual honesty and passion, rejecting orthodoxy and defending the virtue of "nicht mitmachen"- not playing along or compromising in the name of expediency. Those who knew Said would recognize the Adorno-like uncompromising stance of his later years, particularly in his politics.

\section{ORIENTALISM}

The disastrous Arab defeat of 1967 and the encounter with Ibrahim AbuLughod ${ }^{18}$ around the same time played a decisive role in Edward Said's intellectual re-orientation tow ard his Arab identity and culture. Abu-Lughod recruited him to the Association of Arab American University Graduates (AAUG) and, at the height of the anti-Arab media frenzy in 1968, asked him to w rite an article about the Arab character in English literature for a special issue of the Arab World that he was editing. ${ }^{19}$ This was the first academic text Said ever wrote on an Arab topic, ${ }^{20}$ and since it dealt with the question of representation (or rather, misrepresentation) of an entire culture, there was some speculation as to whether this was the seed from which the Orientalism project germinated. 
Said himself definitively settled the matter when he wrote in his homage to Abu-Lughod, "I used the occasion [of writing the article] to look at the image of the Arabs in the media, popular literature and cultural representations going back to the Middle Ages. This was the origin of my book Orientalism, which I dedicated to Janet and Ibrahim."21 From that time forward, Said's interest in and engagement with the Arab world in general, and the Palestinian question in particular, never flagged.

It would, however, be simplistic to reduce Said's re-engagement with the Arab world to this, for it was a lengthy process, as he indicates in Out of Place. Said was a highly driven individual who was keen to consolidate his academic achievement through major theoretical work 22 before taking off in new directions. It was not until 1978 that the book that made his international reputation, Orientalism, was published. It is a book that he wrote without interruption in less than a year. It is doubtful that the book would have been written without the ramifications of the 1967 and 1973 wars and his greater involvement in Palestinian politics; it is

\begin{tabular}{c} 
It is doubtful that \\
Orientalism would have \\
been written without the \\
ramifi cations of the 1967 \\
and 1973 wars and Said's \\
greater involvement in \\
Palestinian politics. \\
\hline
\end{tabular}
important to note that between the wars Said had spent a year in Beirut, finishing Beginnings and perfecting his Arabic. ${ }^{23}$ But it was no doubt the coverage of these two wars in the Western media, and the synergy between the words and actions of the Western establishment, that motivated his grand project by directing his attention to the gulf between the reality of the orient and its representation in Western discourse. The end result was the most compelling narrative of European humanism's complicity in the colonial project of subjugating and misrepresenting the orient that exists. Orientalism married the theoretical acuteness and acumen of Beginnings with the inventory of injustices suffered by the orient. This provided the book's powerful theoretical postulations with a strong moral underpinning that not only made it relevant to wronged cultures but also appealed to the humanistic drive at the heart of liberal western culture itself.

While Said had gained some recognition in the field of English literature and modern languages before the publication of Orientalism, he had made little or no impact beyond these circles and was entirely unknown in the Arab world. The breadth of this groundbreaking book's coverage and the originality of its thesis quickly made it an international success. It soon became the cornerstone of a larger project of deconstructing colonial discourses and practices as they impact on culture and politics, values and perception, and literature and identity. With his two subsequent books, The Question of Palestine(1979) and Covering Islam (1981), he provided case studies illustrating his theory of Orientalism. The wide debate triggered by this project has continued to grow ever since, spaw ning the flourishing disciplines of post-colonial criticism, cultural criticism, and new historicism.

Orientalism was the book that introduced Said to the Arab world. Unfortunately, it was badly translated; ${ }^{24}$ as Raw da 'Ashour, a professor of English 
literature and an accomplished novelist and critic, writes in her able study of Said's w ork, "The Arabic translation of Orientalism is confused, ambiguous and suffers from many problems, the most obvious of which is the transformation of a lucid and enjoyable book into a difficult text laden with incomprehensible terminology." 25 Aside from obfuscating his brilliant argument, the translation had an enormous negative impact on his legacy and the perception-or misperception- of his work among Arab intellectuals. Its thick verbosity, pretentious terminology, and confused vocabulary associated him with the type of sterile and problematic language that was the hallmark of the coterie of Adonis, a clique that clung to Said for some time and complicated the way he was perceived in Arab intellectual circles for years. ${ }^{26}$

Thanks to the opacity of the translation, many of the ardent opponents of modernity and Westernization in the Arab world, Islamists and traditionalists, who by virtue of their ideology would logically be the natural enemies of Said's cultural and ideological stance, exuberantly embraced the book. They perceived it as a new rendering of their traditional attack on the orientalists, articulating in the language of their adversaries their grievance and sense of injustice vis-à-vis the West. It is ironic that they saw a text so radically at odds with their ow $n$ approach as an extension of their attack on the work of the orientalists - an attack which in their case had been historically motivated by religious convictions and a belief that the orientalists' aim had been to undermine Islam and distort its image. ${ }^{27}$ Thus, instead of seeing Said's seminal work as exposing (and undermining) the basis and motivation of the orientalist discourse, they considered it the latest in a series of diatribes against the misrepresentation of Islam in European discourse. ${ }^{28}$ In the process, the crux of Said's argument-concerning the dialectics of know ledge and power, the complicity of discourse in the dynamics of hegemony and imperialism, and the fabrication of an inferior orient as justification for its subjugation and conquest-were completely overlooked. Overlooked, too, was the book's insight into how the orient was used by Europe as an image of an absolute "other," inferior and exotic. More importantly, Said's implicit call for the orient to represent itself and purge its culture of the traces and sedimentation of the orientalist legacy was lost. $^{29}$

Though the message of Said's Orientalism was distorted in Arab intellectual circles-and indeed among the wider public through the traditionalists' widely disseminated misrepresentation of his main thesis as a kind of identity politics-the book did spark wide debate on the issues it addressed. A meaningful discussion of its insights had been conducted by those who had read the book in its original English or in French translation, and their numbers grew with time. ${ }^{30}$ In addition, some of the Western writings on Orientalism's theoretical insights were translated into Arabic in the 1990s in a w ay that redressed the balance. Thanks to these efforts, which eventually corrected the earlier misunderstanding of Orientalism, and as a result of the dissemination of Said's later writings and growing engagement with Arab politics, his impact on the Arab intellectual scene over the years could be compared with that of the early 
pioneers of engagement with Western discourse, tow ering figures like Rifa'ah Rafi' al-Tahtawi (1801-73), Ahmad Faris al-Shidyaq (1804-87), and Khayr al-Din al-Tunisi (1810-90).

\section{Said's Traveling Theories in the Arab Worid}

Whatever the damage in Arab intellectual circles caused by the misrepresentation of Orientalism, it was soon overcome by Said's erudition, range, élan, and astonishing productivity. The publication in 1983 of The World, the Text and the Critic, which contains some of his most astute theoretical essays, coincided with the launch in Cairo of Fusul, ${ }^{31}$ the first journal in Arabic dedicated to literary criticism and literary theory. Fusul soon became a pan-Arab cultural forum for theory and critical debates, and within a few years it had energized the Arab critical scene and invigorated its quest for theoretical investigation. It changed the nature of Arab critical discourse and conducted a far-reaching dialogue with many strands of modern critical theory, particularly structuralism, Russian formalism, Marxism, deconstruction, reception theory, and the psychoanalytic interpretation of literature. It is true that in the early years of Fusul the names of Roland Barthes, Michel Foucault, Jacques Derrida, Jacques Lacan, Wolfgang Iser, Walter Benjamin, Terry Eagleton, and Fredric Jameson were encountered far more frequently than Said's and that the quarterly translated works by many of these literary theorists in its pages but nothing by Said. This regrettable situation was corrected with the re-launch in Ramallah in the early 1990s of the Palestinian quarterly, Al-Karmil, which translated a number of his important critical essays. ${ }^{32}$ Even in Fusul, with the maturation of contemporary Arab critical discourse, Said and his ideas gained more currency, as did those of Mikhail Bakhtin, Antonio Gramsci, Pierre Bourdieu, and Gilles Deleuze. This shift can be explained by the ephemeral appeal of structuralism, its predecessors and offshoots, and their ability to lend themselves to an imitative reproduction of their tenets. Arab criticism had to go through this less demanding phase of theorization, borrowing, and adaptation-and what Said called the "remorseless indignation of orthodoxy and the expression of tired advocacy" ${ }^{33}$ - before grappling with the critical theories of the latter group with their more subtle critical insights.

The publication of Said's famous articles "Traveling Theory" 34 and "Traveling Theory Reconsidered" 35 dealt a sharp blow to the prevailing mode of Arab critics, who had long contented themselves with simply replicating Western theory, or, at best, applying its tenets to Arabic texts. The encounter with Said's "traveling theory" encouraged many to shake off their dependency on these theories. More specifically, Said in these two articles argues against turning literary theory into a cultural dogma which, appropriated by schools or institutions, acquires the status of authority to become the closed domain of specialists and acolytes. He argues instead for a theory of permanent dissonance, of deconsecration, decentralization, and demystification, a Gramscian counter hegemony that rejects enslavement to dominant systems. According 
to Said, any study of the way in which theories travel reveals the inevitability of change and transformation at every junction of the journey and with regard to every aspect of the theory - techniques of dissemination, communication, and interpretation. And for Said, with his belief in noncoercive human community, this is as it should be. Theory, as he states in the second essay, "is to travel, always to move beyond its confinements, to emigrate, to remain in a sense in exile... [in] a geographical dispersion of which the theoretical motor is capable... [in a] movement [that] suggests the possibility of different locales, sites, situations for theory without facile universalism or over-general totalizing." 36

Just as in Orientalism he called upon the orient to represent itself and to speak out, here he is arguing for the critic's liberation from the dogma of theory. Said also observed that in "the Arab world there is this tendentious reliance on and even blind replication of unitary theories without a clear effort to change these theories to something relevant to the Arab culture." ${ }^{37}$ Many Arab critics, such as Jabir Asfur (Egypt), Muhammad Barrada (Morocco), Yumna al-'Id (Lebanon), Subhi Hadidi (Syria), and Fakhri Salih (Jordan), to mention but a few, embraced his call and spoke out for the need to liberate Arab critical discourse from the grip of Western theory and the drudgery of imitations. They realized that it is no longer viable to import Western literary theory or to apply it blindly to Arab literary phenomena or text. Nonetheless, it is easier to reject the tyranny of universalism, as Said has shown us the way, than actually to make a lasting contribution to its modification and change. Thus, though many Arab critics have understood Said's lesson that "no one today is purely one thing," 38 the task of dealing with literary theory with creativity, originality, and sophistication and in a way that takes into account cultural pluralism is still in its infancy in Arab critical discourse.

Many Arab critics also understood Said's aversion to linear subsuming histories and the unitary sense of identity, as well as his preference for a contrapuntal approach capable of dealing with the complexity of historical experience. "All cultures," he w rote, "are involved in one another; none is single and pure, all are hybrid, heterogeneous, extraordinarily differentiated and unmonolithic. This, I believe, is as true of the contemporary United States as it is of the modern Arab world." ${ }^{39}$ Admittedly, it is more difficult to practice contrapuntal criticism without the advantage of Said's multicultural erudition and talent for musical elaboration. Nonetheless, precisely because of Said's approach, Arab critics are more confident in using critical notions without being bound by them. The growing sophistication of Arab critical discourse is in part due to Said's contribution, and this greater sophistication in turn contributes to a wider appreciation of his work. It is natural therefore that Said's next major work, Culture and Imperialism (1993), which saw the culmination of his critical project of deconstructing the Western narrative, received considerable attention in Arab intellectual circles long before it was translated into Arabic. It was extensively review ed in the Arab press, quoted in academic papers, and inspired a number of academic studies. In a recent paper, Radwa 'Ashur ${ }^{40}$ enumerates the projects 
inspired by Said's approach undertaken by young researchers in Egyptian universities. A recent example of the book's impact was the fact that the January 2004 conference organized by the Egyptian Society of Literary Criticism took as its main theme "cultural criticism," or al-Naqd al-Thaqafi, the term increasingly used for the critical approach associated with Said.

Interestingly, Arab intellectuals have shown a marked preference for Said's cultural criticism over the post-colonial strand of his work (Naqd ma Ba'd al-Isti'mar) preferred in the West. There are several reasons for this, the most obvious being the deep-rooted Arab sense of cultural confidence deriving from an often exaggerated pride in its classical legacy. This is buttressed by the tendency to understate colonialism's impact on Arab culture; unlike many colonized countries, which adopted the "language of the colonizer" in their writings, pride in the Arabic language and cultural integrity was not eroded by colonialism. With the notable

\begin{tabular}{c}
\hline Interestingly, Arab \\
intellectuals have shown a \\
marked preference for \\
Said's cultural criticism \\
over the post-colonial \\
strand of his work \\
preferred in the West. \\
\hline
\end{tabular}
exception of Algeria, the bulk of Arab cultural output, even during the period of colonialism, was w ritten in Arabic and marked by the quest for national identity and resistance to colonialism. The w orks of those Arabs who did w rite in French or English, even those that achieved prominence, tended to be dismissed by the Arab intellectual mainstream as marginal contributions to the language in which they are written, rather than seen as Arab cultural products. In addition, the early fascination with Western genres, w hich led someone like Naguib Mahfouz, for example, to aspire in the 1940s to emulate Sir Walter Scott's historical novels and in the 1950s the European realistic novel, has receded. By the 1970s and 1980s, Mahfouz was conducting a creative intertextual dialogue in his novels with archetypal Arab narrative forms- for example the folk epic, as in his 1977 novel Malhamatal-Harafish (Harafish), the Arabian Nights, as in his 1982 novel Layali Alf Layla (Arabian Nights and Days), and the dictionaries of the notables, as in his fascinating 1987 novel Hadith al-Sabah wa-1-Masa' (Talk of Morning and Evening). This shift to a creative dialogue with Arab forms and genres coincided with the introduction of Said's critical contribution, leading to the embrace by the Arab intelligentsia of his cultural criticism, seen as a more comprehensive approach to culture and criticism insofar as it brings together history, geography, the notion of know ledge and power, and critical insight. Thus "cultural criticism," in contrast to the post-colonial strand of Said's thought, does not confine itself to issues of representation, but goes beyond them to a more comprehensive reading of the text. The Western response to Said's project, on the other hand, is generally motivated by reading the colonized w ork w ritten in the main languages of the colonizers, namely English and French.

Arab critical discourse is increasingly embracing Said's contribution not only for its critical insights but also for its efforts to liberate Arab criticism from living on the crumbs of Western theory. In particular, Arab critics felt that the absence of an allencompassing theory of Arab culture is responsible for the adoption of imported theories, making their ow $n$ methodologies derivative and ultimately 
trapping them in a methodological nexus against which they rebelled. Said's theories, which they see as a genuine Arab contribution launched into a w orld of creativity and equality, therefore are seen as offering a w ay out of the methodological dependency on the West. Though well aware that Said's contribution is deeply rooted in Western thought and methodology-and indeed is created in a Western language - they put the emphasis on the subversive power of its rebellion against the reigning orthodoxies and methods in the field. Because of Said's towering accomplishments, the trajectory of his intellectual output, and his increasing involvement in Arab cultural and political affairs, he served as a role model for many Arab intellectuals for the last decade of this life. He was often treated as a paragon of wisdom whose words were taken as inspired revelation, something he disliked.

\section{Speaking Truth to Power: Reviving an Arab Tradition OF DiscourSE}

Traditionally, ever since Abu-Dharr al-Ghifari refused to be co-opted by the Ummayad caliphs in the 8th century, Arab culture has revered the oppositional intellectual who articulates the unsaid and speaks truth to pow er. But since the death of the critic, dramatist, and short story w riter Yusuf Idris (1927-91), and the cooption and silencing of most Arab intellectuals, the Arab world has lacked the voice of a strong and effective oppositional intellectual with the stature, recognized achievements, and moral authority needed to speak truth to the corrupt subaltern powers that dominate today's cultural and political scene. It is perhaps this role that is Said's most appealing and lasting contribution to the Arabic cultural scene.

Said described the prevailing situation in the Arab world of the last decades as follows:

In the Arab world, the brave, if airy and sometimes destructive, pan-Arab nationalism of the Nasser period which abated during the 1970s has been replaced with a set of local and regional creeds, most of them administered harshly by unpopular, uninspired minority regimes. They are now threatened by a whole array of Islamic movements. There has remained, however, a secular, cultural opposition in each Arab country; the most gifted w riters, artists, political commentators, intellectuals, are generally a part of it, although they constitute a minority many of whom have been hounded into silence or exile. ${ }^{41}$

Said was well aware that this state of affairs was the product of the unholy alliance between the oil-rich states, a United States increasingly involved in the Middle East, and the corrupt Arab regimes. He was equally aware of the impact of this alliance on what secular intellectuals represent and of the damage inflicted specifically on their secular project and more generally on the wider political and cultural world. This situation, in which intellectuals have 
been co-opted to an extraordinary degree, undermined the legitimacy of the intelligentsia in the eyes of its constituency. Most Arab "intellectuals" were stuck in the habit of mind that Said calls "avoidance" - "that characteristic turning aw ay from difficult and principled position which you know to be the right one, but which you decide not to take. You do not want to ap pear too political; you are afraid of seeming controversial; you need the approval of a boss or an authority figure; you want to keep a reputation for being balanced, objective, moderate." 42 These considerations take an even cruder form in the Arab world, where the issue is not seeming controversial but of being persecuted, harassed, imprisoned, or barred from working or publishing.

At a time of accelerating political deterioration in the Arab world and an unprecedented and widening gap between the aspirations of the people and the actions and discourse of their governments, the secular intellectuals found themselves pressed between the hammer of the illegitimate regimes (which co-opt or silence them) and the anvil of rising Islamic fundamentalism (which marginalizes their role and deprives them of their natural constituency). Both readers and secular intellectuals sought a figurehead, or rather a rallying point, in a fearless vocal intellectual. There was need for an intellectual who speaks for what Franz Fanon, a vital source of Said's thought, called the "w retched of the earth," but also for an ethical approach to politics based on the principles of real justice. In his last decade Said played such a role, not only by his distinguished intellectual project that probed the crucial relationships between history, narrative, and politics, but also by his active involvement in the Palestinian question. The intellectual, for Said,

is an individual with a specific public role in society that cannot be reduced simply to being faceless professional, a competent member of a class just going about her/his business. The central fact for me is, I think, that the intellectual is an individual endowed with a faculty for representing, embodying, articulating a message, a view, an attitude, philosophy or opinion to, as well as for a public ... whose place it is publicly to raise embarrassing questions, to confront orthodoxy and dogma (rather that to produce them), to be someone who cannot easily be co-opted by governments or corporations, and whose raison d'être is to represent all those people and issues that are routinely forgotten or swept under the rug. ${ }^{43}$

This could serve almost as a description of Said himself and his role in the Arab intellectual scene. His blistering attack on the institutional expediency that spew s O rw ellian "new speak" to disguise the truth and stifle morality and justice was among his prized achievements in this respect. In the intellectual vacuum filled with the din of official media and the stifling jargon of conformity, the Arab public was hungry for such a vocal and authoritative voice. This coincided with Said's active presence on the cultural scene, with his regular columns and 
articles in Arabic in Al-Hayat ${ }^{44}$ and in English in Al-Ahram Weekly. Although most of these articles were political journalism rather than scholarship, by virtue of their stance they are on a par with his literary and cultural project in terms of undermining the bastions of regressive traditional power and helping to detonate a wider cultural debate. Here was an Arab intellectual, independent of the various powers that be and representing in the public consciousness achievement and international fame, who was willing to be mobilized on behalf of their ongoing struggle and embattled community.

Said was without doubt a vociferous public critic of these powers. But in playing this role that the Arab public demanded of him, Said was keen to drive home to that public the importance of reconciling "one's identity and the actualities of one's ow n culture, society, and history to the reality of other identities, cultures, peoples. This can never be done simply by asserting one's preference for what is already one's own: tub-thumping about the glories of 'our' culture or the triumphs of 'our' history is not worthy of the intellectual's energy, especially not today when so many societies are comprised of different races and backgrounds as to resist any reductive formulas." ${ }^{45}$ In other words, he felt strongly about the need to re-educate the public in order to bring it along. It may not be possible to measure the success of his efforts, but his message is being filtered through the writing of many Arab intellectuals. The Egyptian critic Jabir 'Asfur, for example, develops in his recent books a new language and critical idiom drawn from Said's. ${ }^{46}$ In addition, two major Arabic periodicals dedicated recent issues to his work. ${ }^{47}$

Although Said's project is passionately persuasive, it defies closure and certainty. The fact that his work is purely secular increases its appeal both to Arab intellectuals and a wider public. What enlarges his constituency even more is the trajectory of his intellectual orientation outlined in the first part of this essay, which gives his work a legitimacy and authenticity that enhances its relevance for the contemporary Arab scene. Indeed, his intellectual trajectory in some ways parallels that of Arab culture, which began the modern era with an unquestioning acceptance of the western model but which, under the impact of cumulative "hurt" and "injustice" suffered at the hands of the West, began to rethink the unconditionality of that acceptance. The parallel ends there, of course, for in the case of the Arab world, this questioning led some to reject the West totally and, more generally, was accompanied by regression and despondency. To this situation Edward Said brought a breeze of fresh air with his secular criticism, penetrating insight, and courage. I am sure that in the years to come his impact on Arab culture, as elsew here, will grow and flourish. For the changes he has already engendered cannot be easily reversed.

\section{NoTES}

1. Edward Said, Representations of the Intellectual: The 1993 Reith Lectures (London: Vintage Books, 1994), p. 9.

2. This interaction began in the seventh century and reached its peak in the ninth and tenth centuries. This was a period of expansion in the Islamic world, with acquisition of knowledge regardless 
of origin. It started with the translation of Greek, Syriac, Aramaic, and Hellenic works into Arabic. In 830 Bayt al-Hikma, House of Wisdom, was established as an institution wholly devoted to translation. Its mirror image, when the Europeans adopted and translated Arabic knowledge and works, took place after the Crusades, between the twelfth and fifteenth centuries. The interaction in these two phases was marked by peaceful interchange, where the self was dealing with the knowledge of an absent other. By contrast, the third phase of the Arab interaction with the West, which began in the nineteenth century, is marked by tension, conflict, and power politics.

3. For a detailed study of the process of cultural transition, see my book The Genesis of Arabic Narrative Discourse: A Study in the Sociology of Modern Arabic Literature (London: Saqi Books, 1993).

4. Al-Sa'ih, edited by 'Abd al-Masih Hadad (1881-1950), ran from 1912 to 1924; al-Funun, edited by the Palestinian Nasib 'Aridah (1887-1946), was published from 1913 to 1918.

5. Other members of the group were Mikha'il Nu'aimah (1889-1978), Nasib 'Aridah (1887-1946), Rashid Ayyub (1881-1941), 'Abd al-Masih Hadad (1881-1950), and Amin al-Rihani (1867-1940).

6. The main members of this group are 'Abbas Mahmud al-'Aqqad, Ibrahim 'Abd al-Qadir al-Mazin (1890-1949) and 'Abd al-Rahman Shukri (1886-1958), the most poetically gifted of the three. It was Shukri who introduced his group to the major works of English romanticism after his return from two years in England.

7. Another Mahjar group, al-Usbah al-Andalusiyyah (the Andalusian League), was formed in 1932 in San Paulo. The famous members of the group were Ilya Abu-Madi (1890-1957), Rashid Salim al-Khuri (1887-1984), Ilyas Farahat (1893-1977), Faw zi al-Ma'luf (1899-194?), and Michel Ma'ruf.

8. When 'Abbas Mahmud al-'Aqqad (1889-1964), the leading figure of the Diwan, discovered the w ork of the diaspora counterpart in the early 1920s, he perceived them as a vindication of Diwan's ideas, which had been meeting strong resistance at the time, and republished a number of them.

9. Though based in Cairo, the Apollo
Group had members throughout the Arab world.

10. For a detailed account of Said's father's years in the United States, see chapter 1 of Edward W. Said, Out of Place (New York: Alfred A. Knopf, 1999).

11. In addition to Edward (who, as he tells us in the opening pages of Out of Place, looked upon his Western name as a burden), there was Gerald, Rose-Mary, Jean, Joyce, and Grace.

12. Edward Said, Out of Place, p. 44.

13. Ibid., 45.

14. His doctoral thesis was later published as his first book, Conrad and the Fiction of Autobiography (Cambridge: Harvard University Press, 1966).

15. Edward Said, Out of Place, p. 229.

16. For instances in which he felt "hurt" and "injustice," see Ibid., p. 248.

17. The major critics of this school are Marcel Raymond, Georges Poulet, and Jean-Pierre Richard. Their work employs the phenomenological philosophy of Edmund Husserl, the existential phenomenology of Martin Heidegger, and the perceptive phenomenology of Merleau-Ponty. They developed the early phenomenological criticism of Roman Ingarden into a complex critical approach that probes the texts for key signs and recurring metaphors to elaborate the structure of its consciousness.

18. See Said's account of this encounter and the impact of his friendship with Abu-Lughod on his life and thought in "My Guru: The Death of a Palestinian Intellectual," London Review of Books 23, no. 24 (13 December 2001), pp. 19-20.

19. Arab World was the monthly magazine published by the Arab League in New York.

20. Salman Abu-Sittah relates Abu-Lughod's account of his first encounter with Said in the 1950s at Princeton University. Abu-Lughod had introduced himself as a Palestinian, and Said jumped off his chair saying, "Me too." When the AAUG was established in 1968, Abu-Lughod remembered this brief encounter and asked Said to join AAUG and to $w$ rite the article. See Al-Kutub Wijhat Nazar 61 (February 2004), p. 80.

21. Edward Said, "My Guru," p. 19.

22. Particularly in Beginnings:

Intentions and Method (1975) and in most of the studies that appeared later in his The World, the Text and the Critic (1983). 
23. In an interview with Subhi Hadidi, Said mentions as sources of inspiration for his book his return to his Palestinian identity, his sabbatical in Beirut, his study of Arabic language in 1972, and the 1973 war. See Subhi Hadidi, ed., Ta'qibat 'ala al-Istishraq [Postscripts on Orientalism] (Beirut: n.p., 1996).

24. The book was translated into Arabic by Kamal Abu-Deeb as Al-Istishraq: al-Ma'rifah, al-Sultah, al-Insha' and published in Beirut in 1981.

25. Radwa 'Ashour, "Hikayat Edw ard," Al-Kutub Wijhat Nazar 85 (November 2003), p. 14.

26. It was Adonis who introduced one of his disciples to Said, who translated Orientalism and Culture and Imperialism. With Said's wider involvement in the Arab intellectual scene, he came to realize the negative repercussions to his work and distanced himself from this group; his subsequent work had a different translator into Arabic.

27. This is the case in Husain al-Harrawi, al-Mustashriqun wa-l-Islam (Orientalists and Islam, 1936), Bint al-Shati', Turathuna al-Thaqafi bayn Aydi al-Mustashriqin (Our Cultural Legacy in the Hands of O rientalists, 1957), Najib al-'Aqiqi, al-Mustashriqun (The Orientalists, 1965), and Malik Ibn Nabiyy, Intaj al-Mustashriqin wa-Ara'uhum fi rhe Fikr al-Islami al-Hadith (The Work of the Orientalists and its Impact on Modern Islamic Thought, 1969).

28. See for example 'Abd al-Rahman Badawi, Mawsu'at al-Mustashriqin (Encyclopedia of the Orientalists, 1984), Salim Yafut, Hafriyyat al-Istishraq (Archaeology of Orientalism, 1989), and Salim Humaish, al-Istishraq fi Ufuq Insidadih (Orientalism in Its Closed Horizon, 1991).

29. The main exception in this regard is Sadik Jalal al-'Azm, "Orientalism and Orientalism in Reverse," Khamsin 8 (1981).

30. See for example Salim Yafut, Hafriyyat al-Istishraq (Archaeology of Orientalism, 1989), Salim Humaish, al-Istishraq fi Ufuq Insidadih (Orientalism in Its Closed Horizon, 1991), and Falih 'Abd al-Jabbar, Al-Istishraq wa-l-Islam (Orientalism and Islam, 1991).

31. Fusul: Majallat al-Naqd al-Adabi (Fusul: A Journal of Literary Criticism) began publication in 1982 .

32. See for example Al-Karmil issues $48,49,68$, and 72-73, which all have translated essays by Said.

33. Edward Said, Reflections on Exile and Other Literary and Cultural Essays (London: Granta Books, 2000), p. 452.

34. Edward Said, The World, The Text, and the Critic (Cambridge: Harvard University Press, 1983), pp. 226-47.

35. Edward Said, Reflections on Exile, pp. 436-52.

36. Ibid., 452.

37. Subhi Hadidi, Ta'qibat 'ala al-Istishraq, p. 142.

38. Edward Said, Culture and Imperialism (London: Chatto and Windus, 1993), p. 407.

39. Ibid., xxix.

40. A paper submitted to a conference on History and the Text organized by the Faculty of Letters and Humanities of Kairoun University, Tunisia, 2003.

41. Edward Said, Representations of the Intellectual, p. 86.

42. Ibid., 74

43. Ibid., 9.

44. In his later years, Said was clearly aware of the mixed messages involved in writing for Al-Hayat as a Saudi-ow ned paper. He justified it by his need to communicate with the wider Arab audience, which this new spaper undoubtedly reached. Thus, while his political stance was unequivocal, its publication in this new spaper often led to misunderstanding and ambiguity.

45. Edward Said, Representations of the Intellectual, p. 69.

46. See his books, Nazariyyat Mu'asirah (Contemporary Theories, 1998), in which he deals directly with Said's many works, and Afaq al-Asr (Horizons of our Time, 1997).

47. See the December 2003 issue of Al-Adab monthly (published in Beirut), which is entitled "Edw ard Said: His Impact on the World and on the U.S.," and Al-Karmil 78 (Winter 2004). 